\title{
HUBUNGAN ANGKA KECUKUPAN ZAT BESI DAN VITAMIN C DENGAN KEJADIAN ANEMIA PADA IBU HAMIL
}

\section{RELATIONSHIP BETWEEN IRON AND VITAMIN C ADEQUACY RATES WITH THE INCIDENCE OF ANEMIA}

\author{
Andi Hikma Padaunga1*, Sitti Mukarramah²

\begin{abstract}
*1Politeknik Kesehatan Makassar, Jl. Bendungan Bili-bili No. 1 Tidung Makassar, email: andihikmapadaunga@gmail.com, Indonesia

2Politeknik Kesehatan Makassar, Jl. Bendungan Bili-bili No. 1 Tidung Makassar, email: sitti_mukarramah@poltekkes-mks.ac.id, Indonesia
\end{abstract}

\begin{abstract}
Background: Anemia in pregnancy is one of the conditions where the hemoglobin level is lower than the normal level, which is $<11 \mathrm{~g} / \mathrm{dl}$. The nutritional adequacy rate of pregnant women have a role in the process of anemia. Diversity in food consumption have an important role in helping to increase iron substance absorption in the body.

Objective: To determine the relationship of iron substance and vitamin $\mathrm{C}$ adequacy rates with the incidence of anemia in third trimester pregnant women.

Methods: This study is observational research with a cross sectional study approach. Sampling by using simple random sampling method for 47 subjects pregnant women of third trimester was determined by using the Lemeshow formula. Data analysis using Chi-Square test.

Results: The relationship between the adequacy rate of iron substance and the incidence of anemia is strong, obtained $p$ values is 0,000 and Phi $(\mu) 0.71$. It also the relationship between the adequacy of vitamin $\mathrm{C}$ and the incidence of anemia very strong closed to perfect, obtained p values is 0,000 and Phi $(\mu) 0.93$.

Conclusion: that there is a significant relationship between the adequacy rate of iron substance and vitamin $\mathrm{C}$ with the incidence of anemia in third trimester pregnant women.
\end{abstract}

Keywords: Anemia, Iron, Vitamin C

\section{PENDAHULUAN}

Kesejahteraan suatu negara dapat dilihat dari tingginya angka kesakitan dan kematian ibu (AKI). Angka kematian ibu di suatu negara merupakan gambaran dari status gizi, kesehatan ibu, dan tingkat pelayanan kesehatan terutama bagi ibu hamil, melahirkan dan nifas. Menurut Survei Demografi dan Kesehatan Indonesia (SDKI) tahun 2015 angka kematian ibu masih tinggi yaitu 305 per 100.000 kelahiran hidup meskipun angka ini sedikit menurun jika dibandingkan dengan tahun 2012 yaitu 359 per 100.000 kelahiran hidup. Hal ini menunjukkan bahwa potensi untuk mencapai salah satu target pembangunan berkelanjutan yang tertuang dalam Sustainable Development Goals (SDGs) pada tujuan ke-3 yaitu mengurangi rasio angka kematian ibu menjadi kurang dari 70 per 100.000 kelahiran hidup pada tahun 2030 masih sangat jauh. Terdapat tiga penyebab utama kematian ibu yakni perdarahan, hipertensi dan infeksi. Salah satu penyebab tidak langsung terjadinya perdarahan yaitu anemia yang dialami selama kehamilan. ${ }^{1}$

Anemia merupakan salah satu masalah kesehatan nasional yang saat ini masih dialami oleh ibu hamil. Anemia walaupun merupakan kondisi yang sifatnya 
fisiologis dan hampir dialami oleh setiap ibu hamil karena adanya proses fisiologis yaitu terjadinya pengenceran darah akibat peningkatan plasma darah atau yang lazim disebut dengan hemodilusi. Namun hal tersebut akan menjadi patologis bila tidak dilakukan upaya untuk meminimalisirnya. ${ }^{2}$

Anemia pada ibu hamil sangat berpotensi untuk membahayakan ibu dan anaknya. Dampak anemia tidak hanya terjadi selama kehamilan namun juga dapat berlanjut pada persalinan bahkan setelah persalinan. Ibu hamil dengan anemia beresiko terjadi abortus, persalinan prematuritas, dekompensasi kordis, dan ketuban pecah dini. Sedangkan anemia yang berlanjut pada persalinan dan setelahnya dapat mengakibatkan gangguan his, retensio plasenta, dan perdarahan post partum karena atonia uteri. ${ }^{3}$

Secara global menunjukkan bahwa $69,0 \%$ wanita hamil mengalami anemia. Asia Tenggara menempati peringkat kedua tertinggi dengan prevalensi 85,6\% dibandingkan dengan Amerika (53,8\%) dan Eropa (8,3\%). ${ }^{4}$ Berdasarkan hasil Riskesdas 2013 proporsi anemia pada ibu hamil sebanyak $37,1 \%$ sedangkan hasil Riskesdas 2018 proporsi anemia pada ibu hamil sebanyak $48,9 \%$. Hal ini menunjukkan bahwa adanya peningkatan derajat kejadian anemia pada ibu hamil di Indonesia. ${ }^{5}$

Prevalensi anemia ibu hamil di Sulawesi Selatan melebihi angka nasional dan tergolong sebagai masalah yang cukup berat. Berdasarkan hasil Binkesmas Dinas Kesehatan Provinsi Sulawesi Selatan tahun 2015 yang dikutip dalam jurnal Wahyuni Mansyur (2017) dari 23.839 ibu hamil yang di dilakukan pemeriksaan hemoglobin, terdapat 23.478 ibu hamil $(98,49 \%)$ dengan kadar hemoglobin 8-11 $\mathrm{mg} / \mathrm{dl}$ atau mengalami anemia sedang dan ringan. Terdapat $361 \mathrm{ibu}$ hamil $(1,15 \%)$ dengan kadar hemoglobin $<8$ $\mathrm{mg} / \mathrm{dl}$ atau mengalami anemia berat. $^{6}$

Banyak faktor yang dapat menyebabkan anemia pada ibu hamil. Menurut Istiarti (2012) faktor yang dapat menyebabkan anemia pada ibu hamil diantaranya kepatuhan ibu mengkonsumsi zat besi, kunjungan Antenatal Care (ANC), sikap, paritas, umur, pola makan, social ekonomi, pendidikan dan budaya. Penyebab paling umum dari anemia pada kehamilan adalah defisiensi zat besi. Oleh karena itu penting dilakukan pemeriksaan anemia pada kunjungan pertama kehamilan. Bahkan jika tidak mengalami anemia pada saat kunjungan pertama, masih mungkin terjadi anemia pada kehamilan selanjutnya. Sehingga ibu hamil memerlukan banyak zat gizi untuk memenuhi kebutuhan tubuh pada diri dan janinnya. ${ }^{7}$

Asupan zat gizi berperan dalam pembentukan sel darah merah. Asupan zat gizi yang tidak tercukupi dapat mengganggu pembentukan sel darah merah. Pembentukan sel darah merah yang terganggu bisa disebabkan oleh makanan yang dikonsumsi kurang mengandung zat 
gizi terutama zat gizi penting seperti zat besi, asam folat, protein, vitamin $\mathrm{C}$ dan zat gizi lainnya. Keanekaragaman konsumsi makanan berperan penting dalam membantu meningkatkan penyerapan zat besi di dalam tubuh. Absorbsi besi yang efektif dan efesien memerlukan adanya reduktor seperti vitamin $C$ yang berperan sebagai promotor terhadap absorpsi zat besi. ${ }^{8}$

Hasil studi pendahuluan yang telah dilakukan di Puskesmas Mangasa Kota Makassar pada periode Januari sampai Oktober 2018 terdapat 428 ibu hamil yang datang memeriksakan kehamilan di Puskesmas. Dari 358 ibu hamil yang dilakukan pemeriksaan kadar hemoglobin terdapat 185 ibu hamil (48,3\%) dengan kadar hemoglobin $<11 \mathrm{gr} / \mathrm{dl}$.

Berdasarkan uraian di atas maka penulis tertarik melakukan penelitian untuk mengetahui adanya hubungan antara angka kecukupan zat besi dan vitamin $\mathrm{C}$ dengan kejadian Anemia pada Ibu Hamil Trimester III di Puskesmas Mangasa Kota Makassar.

\section{BAHAN DAN CARA PENELITIAN}

Penelitian ini menggunakan penelitian observational dengan pendekatan cross sectional study yang bertujuan untuk membuktikan hubungan asupan zat besi dan vitamin $\mathrm{C}$ dengan kejadian anemia pada ibu hamil trimester III di Puskesmas Mangasa kota Makassar.

Penelitian ini dilaksanakan pada bulan Februari s/d Mei 2019 di Wilayah Kerja
Puskesmas Mangasa Kota Makassar dengan melibatkan 47 ibu hamil trimester III sebagai responden, yang ditentukan menggunakan formulasi Lemeshow. Pengambilan sample dengan metode simple random sampling. Pengumpulan data dilakukan dengan wawancara recall 24 jam dilakukan selama 3 hari tidak berturut-turut. Instrumen penelitian yang digunakan yaitu formulir food recall untuk mengetahui makanan dan minuman yang dikonsumsi oleh responden selama 24 jam terakhir, Easy Touch GCHb untuk mengetahui kadar hemoglobin responden. Data hasil recall dihitung menggunakan aplikasi nutrisurvey. Analisis statistik uji Chisquare dengan menggunakan Fisher's Exact Test.

\section{HASIL DAN PEMBAHASAN}

\section{Data Karakteristik Subjek}

Karakteristik subjek menjelaskan tentang ciri-ciri fisik subjek yang terdiri atas umur, paritas, dan jarak kehamilan.

Tabel 1. Distribusi subjek berdasarkan karakteristik ibu hamil di Puskesmas Mangasa Kota Makassar tahun 2019

\begin{tabular}{|c|c|c|c|}
\hline Karakteri & Responden & (f) & $(\%)$ \\
\hline \multirow{3}{*}{ Umur } & $<20$ tahun & 9 & 19,1 \\
\hline & 20-35 tahun & 33 & 70,2 \\
\hline & $>35$ tahun & 5 & 10,6 \\
\hline \multirow[b]{2}{*}{ Paritas } & $\leq 4$ Kali & 43 & 91,5 \\
\hline & $>4$ kali & 4 & 8,5 \\
\hline \multirow{3}{*}{$\begin{array}{l}\text { Jarak } \\
\text { Kehamilan }\end{array}$} & Tidak Ada & 20 & 42,6 \\
\hline & $\geq 2$ tahun & 20 & 42,6 \\
\hline & $<2$ tahun & 7 & 14,9 \\
\hline \multicolumn{2}{|c|}{ Total } & 47 & 100,0 \\
\hline
\end{tabular}

Sumber: Data Primer, 2019

Pada tabel 1 menunjukkan bahwa distribusi karakteristik subjek berdasarkan kategori umur dari 47 subjek terdapat 9 
subjek $(19,1 \%)$ yang termasuk dalam kelompok umur $<20$ tahun, 33 subjek $(70,2 \%)$ yang termasuk dalam kelompok umur 20-35 tahun, dan terdapat 5 subjek $(10,6 \%)$ yang termasuk dalam kelompok umur $>35$ tahun. Distribusi karakteristik subjek berdasarkan paritas dari 47 subjek terdapat 43 subjek $(91,5 \%)$ yang memiliki jumlah paritas $\leq 4$ kali dan terdapat 4 subjek (8,5\%) yang memiliki jumlah paritas $>4$ kali. Distribusi subjek berdasarkan jarak kehamilan dari 47 subjek terdapat 20 subjek $(42,6 \%)$ yang belum pernah hamil, terdapat 20 subjek (42,6\%) yang memiliki jarak kehamilan $\geq 2$ tahun, serta 7 subjek $(14,9 \%)$ yang memiliki jarak kehamilan $<2$ tahun.

\section{Analisis Deskriptif}

Analisis deskriptif pada penelitian ini bertujuan untuk melihat frekuensi dan presentase dari variabel dependen yaitu kejadian anemia dan variabel indepeneden yaitu angka kecukupan zat besi dan vitamin C.

Distribusi Subjek Penelitian Berdasarkan Kejadian Anemia

Tabel 2. Distribusi Frekuensi Kejadian Anemia Ibu Hamil Trimester III di Puskesmas Mangasa Kota Makassar tahun 2019

\begin{tabular}{crr}
\hline $\begin{array}{c}\text { Kejadian } \\
\text { Anemia }\end{array}$ & $\begin{array}{c}\text { Frekuensi } \\
\text { (f) }\end{array}$ & \multicolumn{1}{c}{$\begin{array}{c}\text { Persentase } \\
\text { (\%) }\end{array}$} \\
\hline Tidak Anemia & 9 & 19,4 \\
\hline Anemia & 38 & 80,9 \\
\hline Total & $\mathbf{4 7}$ & $\mathbf{1 0 0 , 0}$ \\
\hline
\end{tabular}

Sumber: Data Primer, 2019

Tabel 2 menunjukkan bahwa dari 47 subjek terdapat 38 subjek (80,9\%) mengalami anemia dengan kadar Hemoglobin <11 gr/dl dan 9 subjek $(19,4 \%)$ yang tidak anemia dengan kadar Hemoglobin $\geq 11 \mathrm{gr} / \mathrm{dl}$.

\section{Distribusi Subjek Berdasarkan Angka} Kecukupan Zat Besi

Tabel 3. Distribusi Frekuensi Angka Kecukupan Zat Besi Ibu Hamil Trimester III di Puskesmas Mangasa Kota Makassar tahun 2019

\begin{tabular}{crr}
\hline $\begin{array}{c}\text { Asupan Zat } \\
\text { Besi }\end{array}$ & $\begin{array}{c}\text { Frekuensi } \\
\text { (f) }\end{array}$ & \multicolumn{1}{c}{$\begin{array}{c}\text { Persentase } \\
\text { (\%) }\end{array}$} \\
\hline Cukup & 15 & 31,9 \\
\hline Kurang & 32 & 68,1 \\
\hline Total & $\mathbf{4 7}$ & $\mathbf{1 0 0 , 0}$ \\
\hline Sur
\end{tabular}

Sumber: Data Primer, 2019

Tabel 3 menunjukkan bahwa dari 47 subjek terdapat 15 subjek (31,9\%) yang memiliki asupan zat besi dalam kategori cukup dan terdapat 32 subjek $(68,1 \%)$ memiliki asupan zat besi dalam kategori kurang.

\section{Distribusi Subjek Berdasarkan Angka Kecukupan Vitamin C}

Tabel 4. Distribusi Frekuensi Angka Kecukupan Vitamin C lbu Hamil Trimester III di Puskesmas Mangasa Kota Makassar tahun 2019

\begin{tabular}{crr}
\hline $\begin{array}{c}\text { Asupan } \\
\text { Vitamin C }\end{array}$ & Frekuensi (f) & \multicolumn{1}{c}{$\begin{array}{c}\text { Persentase } \\
(\mathbf{\%})\end{array}$} \\
\hline Cukup & 10 & 21,3 \\
\hline Kurang & 37 & 78,7 \\
\hline Total & $\mathbf{4 7}$ & $\mathbf{1 0 0 , 0}$ \\
\hline
\end{tabular}

Sumber: Data Primer, 2019

Tabel 4 menunjukkan bahwa dari 47 subjek terdapat 10 subjek (21,3\%) yang memiliki asupan vitamin $\mathrm{C}$ dalam kategori cukup dan terdapat 37 subjek $(78,7 \%)$ yang memiliki asupan vitamin $\mathrm{C}$ dalam kategori kurang.

\section{Analisis Inferensial}

Hubungan Angka Kecukupan Zat Besi dengan Kejadian Anemia 
Tabel 5. Hubungan Angka Kecukupan Zat Besi dengan Kejadian Anemia pada Ibu Hamil Trimester III di Puskesmas Mangasa Kota Makassar tahun 2019

\begin{tabular}{|c|c|c|c|c|c|c|c|c|}
\hline \multirow{3}{*}{$\begin{array}{l}\text { Asupan } \\
\text { Zat Besi }\end{array}$} & \multicolumn{4}{|c|}{ Kejadian Anemia } & \multirow{2}{*}{\multicolumn{2}{|c|}{ Total }} & \multirow{3}{*}{$\begin{array}{c}p \\
\text { value }\end{array}$} & \multirow{3}{*}{$\operatorname{Phi}(\mu)$} \\
\hline & \multicolumn{2}{|c|}{$\begin{array}{c}\text { Tidak } \\
\text { Anemia }\end{array}$} & \multicolumn{2}{|c|}{ Anemia } & & & & \\
\hline & $\mathbf{n}$ & $\%$ & $\mathbf{n}$ & $\%$ & $\mathbf{n}$ & $\%$ & & \\
\hline Cukup & 9 & 19,1 & 6 & 12,8 & 15 & 31,9 & & \\
\hline Kurang & 0 & 0 & 32 & 68,1 & 32 & 68,1 & 0,000 & 0,71 \\
\hline Total & 9 & 19,1 & 38 & 80,9 & 47 & 100,0 & & \\
\hline
\end{tabular}

Sumber: Data Primer, 2019

Tabel 5 di atas menunjukkan bahwa dari 47 subjek terdapat 15 subjek (31,9\%) yang memiliki asupan zat besi yang cukup, 9 subjek $(19,1 \%)$ yang tidak mengalami anemia dan 6 subjek $(12,8 \%)$ yang mengalami anemia. Terdapat 32 subjek $(80,9 \%)$ yang memiliki asupan zat besi yang kurang mengalami anemia.

Berdasarkan hasil analisis statistik uji Chi-Square dengan menggunakan Fisher's Exact Test pada tabel di atas diperoleh $p$ value $(0,000)$ pada $\alpha=0,05$ yang berarti $H_{a}$ diterima. Hal ini menunjukkan bahwa terdapat hubungan yang signifikan antara angka kecukupan zat besi dengan kejadian anemia pada ibu hamil trimester III dengan kekuatan hubungan di uji menggunakan pearson correlation sehingga diperoleh nilai koefisien korelasi 0,71 yang berarti bahwa hubungan tersebut termasuk dalam kategori kuat.

Hasil di atas dapat diasumsikan oleh peneliti bahwa ibu hamil yang mendapatkan asupan zat besi yang cukup yakni $\geq 39 \mathrm{mg}$ perhari memiliki kecenderungan untuk tidak mengalami anemia. Sebaliknya, bagi ibu hamil yang mendapatkan asupan zat besi kurang memiliki kecenderungan untuk mengalami anemia. Namun demilkian beberapa ibu hamil yang mendapatkan asupan zat besi yang memadai ternyata masih teridentifikasi mengalami anemia. Hal tersebut dapat terjadi mungkin karena adanya faktor yang bersifat individualis antara lain faktor yang dapat menghambat penyerapan zat besi tersebut. Oleh karena itu kecukupan asupan zat besi belum dapat menjamin kebutuhan individu terpenuhi, termasuk ibu hamil agar terhindar dari anemia.

Beberapa faktor penghambat penyerapan zat besi antara lain zat tanin, fitat, oksalat dan kalsium (terkandung dalam kopi, teh dan susu) yang akan mengikat zat besi sebelum diserap oleh mukosa usus menjadi zat yang tidak dapat larut, sehingga akan mengurangi penyerapan zat besi. $^{7}$ Faktor lain yang menjadi pemicu kejadian anemia pada ibu hamil yang memiliki asupan zat besi yang cukup yaitu, adanya proses hemodilusi yang terjadi pada ibu hamil. Puncak hemodilusi pada ibu hamil terjadi pada trimester III di usia kehamilan 32 sampai 36 minggu. ${ }^{10}$

Sebagian besar subjek penelitian mengkonsumsi lauk hewani (telur, ikan, daging, seafood) lauk nabati (tahu, tempe), sayuran dan makanan instan seperti indomie. 
Kebiasaan makan subjek penelitian masih kurang dilihat dari asupan zat besi pada subjek masih banyak yang termasuk dalam kategori kurang. Tingginya persentase asupan zat besi yang kurang pada subjek disebabkan karena, kebanyakan responden mengkonsumsi sumber makanan zat besi non-heme yang berasal dari tumbuhan yang memiliki daya serap lebih rendah sekitar 1$7 \%$ dibandingkan dengan sumber makanan zat besi heme yang memiliki daya serap sekitar $25-30 \%$.

Hal lain yang mungkin menjadi penyebab tingginya persentase asupan zat besi yang kurang pada subjek dikarenakan, hanya sebagian dari subjek yang rutin mengkonsumsi tablet zat besi. Dari 47 subjek yang diteliti tidak ada yang mampu mencapai angka kecukupan asupan zat besi sesuai dengan yang ditetapkan yaitu $\geq 39 \mathrm{mg}$ perhari. Namun dengan adanya penambahan tablet tambah darah ( $\mathrm{Fe}$ ) sebanyak $60 \mathrm{mg}$ perhari mampu menutupi ketidakcukupan tersebut.
Zat besi sangat dibutuhkan oleh ibu hamil untuk mencegah terjadinya anemia dan menjaga pertumbuhan janin secara optimal. Dampak anemia tidak hanya terjadi selama kehamilan namun juga dapat berlanjut pada persalinan bahkan setelah persalinan. Ibu hamil dengan anemia beresiko terjadi abortus, persalinan prematuritas, dekompensasi kordis, dan ketuban pecah dini. Sedangkan anemia yang berlanjut pada persalinan dan setelahnya dapat mengakibatkan gangguan his, retensio plasenta, dan perdarahan post partum karena atonia uteri. $^{3}$

Hasil penelitian ini sejalan dengan penelitian Setyaningsih, dkk (2015) yang menyatakan bahwa tingkat kecukupan zat besi secara statistik memiliki hubungan yang bermakna terhadap resiko terjadinya anemia pada ibu hamil.

\section{Hubungan Angka Kecukupan Vitamin C dengan Kejadian Anemi}

Tabel 6. Hubungan Angka Kecukupan Vitamin C dengan Kejadian Anemia pada Ibu Hamil Trimester III di Puskesmas Mangasa Kota Makassar tahun 2019

\begin{tabular}{|c|c|c|c|c|c|c|c|c|}
\hline \multirow{3}{*}{$\begin{array}{c}\text { Asupan } \\
\text { Vitamin C }\end{array}$} & \multicolumn{4}{|c|}{ Kejadian Anemia } & & & \multirow{3}{*}{$\begin{array}{c}p \\
\text { value }\end{array}$} & \multirow{3}{*}{$\operatorname{Phi}(\mu)$} \\
\hline & \multicolumn{2}{|c|}{$\begin{array}{c}\text { Tidak } \\
\text { Anemia }\end{array}$} & \multicolumn{2}{|c|}{ Anemia } & \multicolumn{2}{|c|}{ Total } & & \\
\hline & $\mathbf{n}$ & $\%$ & $\mathbf{n}$ & $\%$ & $\mathbf{n}$ & $\%$ & & \\
\hline Cukup & 9 & 19,1 & 1 & 2,1 & 10 & 21,3 & & \\
\hline Kurang & 0 & 0 & 37 & 78,7 & 37 & 78,7 & 0,000 & 0,936 \\
\hline Total & 9 & 19,1 & 38 & 80,9 & 47 & 100,0 & & \\
\hline
\end{tabular}

Tabel 6 menunjukkan bahwa dari 47 subjek terdapat 10 subjek $(21,3 \%)$ yang memiliki asupan vitamin C cukup, 9 subjek $(19,1 \%)$ yang tidak anemia dan 1 subjek $(2,1 \%)$ yang mengalami anemia. Terdapat 37 subjek $(78,7 \%)$ memiliki asupan vitamin C kurang dan mengalami anemia.

Berdasarkan hasil analisis statistik uji Chi-Square dengan menggunakan Fisher's Exact Test pada tabel di atas diperoleh $p$ 
value $(0,000)$ pada $\alpha=0,05$ yang berarti $H_{a}$ diterima. Hal ini menunjukkan bahwa terdapat hubungan yang signifikan antara angka kecukupan vitamin $\mathrm{C}$ dengan kejadian anemia pada ibu hamil trimester III dengan kekuatan hubungan di uji menggunakan pearson correlation sehingga diperoleh nilai koefisien korelasi 0,93 yang berarti bahwa hubungan tersebut termasuk dalam kategori sangat kuat atau mendekati sempurna.

Dari hasil diatas peneliti berasumsi bahwa ibu hamil yang mendapatkan asupan vitamin $C$ yang cukup yaitu $\geq 85 \mathrm{mg}$ perhari memiliki kecenderungan untuk tidak mengalami anemia, sebaliknya ibu hamil yang mendapatkan asupan vitamin $\mathrm{C}$ yang kurang memiliki kecenderungan untuk mengalami anemia. Namun demikian ternyata masih terdapat ibu hamil yang memiliki asupan vitamin C cukup teridentifikasi mengalami anemia. Tingginya presentase subjek yang memiliki angka kecukupan vitamin $\mathrm{C}$ dalam kategori kurang dikarenakan hanya sebagian dari subjek yang mengkonsumsi makanan sumber vitamin C seperti pepaya, melon, pisang, langsat, rambutan dan lain-lain serta hanya sebagian kecil dari subjek yang rutin mengkonsumsi suplemen vitamin $\mathrm{C}$.

Vitamin C juga dibutuhkan selama kehamilan berfungsi untuk membantu penyerapan besi non heme dengan mereduksi besi ferri menjadi ferro dalam usus halus sehingga mudah diabsorpsi. Vitamin C menghambat pembentukan hemosiderin yang sukar dimobilisasi untuk membebaskan besi bila diperlukan, sehingga risiko anemia defisiensi zat besi bisa dihindari. ${ }^{11}$

Hasil penelitian ini juga sejalan dengan penelitian Devani, dkk (2015) yang menyatakan bahwa ada hubungan asupan vitamin $\mathrm{C}$ dengan kadar hemoglobin yang dapat dilihat berdasarkan status anemia ibu hamil.

\section{KESIMPULAN}

Berdasarkan hasil penelitian yang telah dilakukan dapat disimpulkan bahwa semakin tinggi asupan zat besi dan vitamin C seseorang maka pelung terjadinya anemia semakin kecil pula. Hal ini menunjukkan bahwa terdapat hubungan yang signifikan antara angka kecukupan zat besi dan vitamin C dengan kejadian anemia pada ibu hamil trimester III di Puskesmas Mangasa Kota Makassar. Sesuai dengan hasil penelitian yang diperoleh, peneliti berharap kepada pihak klinik untuk memberikan informasi kepada ibu hamil tentang cara pemilihan makanan yang mengandung zat besi dan vitamin $\mathrm{C}$ untuk mencegah terjadinya anemia selama kehamilan. Hasil penelitian ini dapat digunakan sebagai dasar penelitian lain dan diharapkan bagi peneliti selanjutnya dapat melakukan penelitian yang sejenis dengan melihat aspek lain yang dapat mempengaruhi kejadian anemia pada ibu hamil sehingga dapat diatasi untuk meningkatkan kesejahteraan ibu dan janinnya selama kehamilan. 


\section{TERIMA KASIH}

1. Bapak Ir. Agustian Ipa, M.Kes. selaku Direktur Politeknik Kesehatan Makassar

2. Ibu Hj. Suriani B, SKM., M.Sc. selaku Ketua Jurusan Kebidanan Politeknik Kesehatan Makassar. Email: Suriani_b503@poltekkes-mks.ac.id.

3. Ibu Hj. Sitti Mukarramah, S.ST., M.Keb. selaku Ketua Program Studi DIV
Kebidanan Politeknik Kesehatan
Makassar.
sitti_mukarramah@poltekkes-mks.ac.id.

\section{KEPUSTAKAAN}

1. Kementerian Kesehatan Republik Indonesia. Profil Kesehatan Indonesia 2015. Jakarta: Kementrian Kesehatan R.I.; 2016.

2. Prahesti R. Analisis Faktor-faktor yang Berhubungan dengan Kejadian Anemia pada Ibu Hamil di Puskesmas Prambanan Sleman Yogyakarta. Skripsi tidak diterbitkan. Surakarta: Pascasarjana Universitas Sebelas Maret. 2017.

3. Handayani, T.R. Determinan Kejadian anemia Defesiensi Zat Besi pada Ibu Hamil di Puskesmas Nagaswidak Palembang. E-Jurnal STIKes. 2017; Vol. 5, (2), Hal. 347

4. World Healt Organization (WHO). Proportion (\%) of population covered by anaemia prevalence surveys (national or sub-national) between 1993 and 2005; 2008.

5. Kementerian Kesehatan RI. Hasil Utama Riskesdas. Jakarta: Badan Penelitian dan Pengembangan Kesehatan. 2018.

6. Mansyur W. Pengaruh Pemberian Brownis Tempe Subtitusi Wortel (Daucus Carota L.) terhadap Kadar Hemoglobin (Hb) pada Ibu Hamil Anemia di Wilayah Kerja Puskesmas Pertiwi Kecamatan Mariso Kota Makassar. Karya Tulis IImiah tidak diterbitkan. Makassar:
Fakultas Kedokteran dan IImu Kesehatan UIN Alauddin; 2017.

7. Yuliani T. Hubungan Pola Makan dan Kepatuhan Mengkonsumsi Tablet $\mathrm{Fe}$ dengan Kejadian Anemia dalam Kehamilan di Wilayah Kerja Puskesmas Andoolo Utama. Skripsi Tidak diterbitkan. Kendari: Program Studi Diploma IV Kebidanan Politeknik Kesehatan Kendari; 2018.

8. Saptyasih, A.R.S. Widajayanti L. Nugraheni, S.A. Hubungan Asupan Zat Besi, Asam Folat, Vitamin $B_{12}$ dan Vitamin C dengan Kadar Hemoglobin Siswa di SMP Negeri 2 Tawangharjo Kabupaten Grobongan. Jurnal Kesehatan Masyarakat. 2016; Vol. 4, (4), Hal. 522

9. Riswanda, J. Hubungan Asupan Zat Besi Dan Inhibitornya sebagai Prediktor Kadar Hemoglobin Ibu Hamil di Kabupaten Muara Enim. Jurnal Biota. 2017; Vol. 3, (2), Hal. 88

10. Proverawati. Asfuah S. Buku Ajar Gizi untuk Kebidanan. Yogyakarta: Nuha Media; 2009.

11. Seri, L.A. Buku Saku Anemia Defisiensi Besi. Jakarta: EGC; 2016. 